\title{
GIS- based Land Suitability Analysis Using AHP for Public Parks Planning in Larkana City
}

\author{
Imtiaz Ahmed Chandio (Corresponding author) \\ $\mathrm{PhD}$ Student, Department of Civil Engineering, Universiti Teknologi Petronas \\ Bandar Seri Iskandar, 31750 Tronoh, Perak Darul Ridzuan, Malaysia \\ Tel: 60-12-279-6324 E-mail:imtiazutp@gmail.com
}

\author{
Abdul-Nasir Matori \\ Associate Professor, Department of Civil Engineering, Universiti Teknologi Petronas \\ Bandar Seri Iskandar, 31750 Tronoh, Perak Darul Ridzuan, Malaysia \\ Tel: 60-12-437-1617Ｅ-mail:nasrat@petronas.com.my \\ Dano Umar Lawal \\ $\mathrm{PhD}$ Student, Department of Civil Engineering, Universiti Teknologi Petronas \\ Bandar Seri Iskandar, 31750 Tronoh, Perak Darul Ridzuan, Malaysia \\ Tel: 60-17-736-6200Ｅ-mail:bblawaldano@gmail.com \\ Soheil Sabri \\ PhD Student, Department of Urban and Regional Planning, Universiti Teknologi Malaysia \\ 81310, Skudai, Johor, Malaysia \\ Tel: +60127798025Ｅ-mail: Soheilsabri@gmail.com
}

Received: March 21, 2011

Accepted: April 25, 2011

doi:10.5539/mas.v5n4p177

\begin{abstract}
Optimal locations for public facilities such as public parks are significant issues in the urban planning of Larkana city. Therefore, specifically, Larkana city of Pakistan is selected as the study area where the land suitability model was applied to determine suitable land for public parks. This study was carried out within the framework of an Analytic Hierarchy Process (AHP) as a multi-criteria evaluation approach by integrating it with the Geographic Information System (GIS). Decision support system software called Expert choice 11.5 was used to calculate the weights based on three alternative scenarios. Computed composite weights were inserted into the spatial analysis function of GIS and produced three scenarios of suitability maps, i.e.: (a) land availability, (b) land value and (c) population density. Hence, based on the analysis and findings made in this research, finding suitable locations using the land suitability model for future park development is highly helpful. Results can be useful in the planning of public facilities and future land use planning in Larkana city.
\end{abstract}

Keywords: GIS, AHP, Expert choice, Land suitability, Optimal locations

\section{Introduction}

A built environment represents a high level of interference in the ecological system, changing the landscape and intervening with natural processes permanently. Parks are classified into two major categories, such as provision of recreation, services to society and conservation of natural values (Maruani and Amit-Cohen, 2007). Keeping in view, parks and green spaces control the rising temperature in urban areas and provide a healthy urban environment (Barbosa et al. 2007). In addition, less attention is paid to protect the urban parks (Thompson, 2002) and their sustainability (Chiesura, 2003). Uncontrolled human activities have increased tremendously. As a result, the existing parks and open spaces are encroached into a built environment in developing countries like Pakistan's cities (Adeel, 2010). Hence, the main objective of this paper is to identify and evaluate the existing public parks in Lankana City by finding the most suitable site to locate the public park based on an integrated GIS multi-criteria evaluation technique. There are various methods used in GIS in evaluating land suitability, e.g. Murrey, 2003 applied a location model; Graymore et al., 2009, produced an index of regional sustainability spatial decision support system; Saaty, R.W., 2003 and Abadi, 2007, used an analytic network process; and Mohit and Ali, 2006 integrated an analytic hierarchy process with GIS. In this study, a GIS-based AHP was used to determine land suitability for parks, which has been a very useful method over the years. GIS plays a vital role in planning for many decades of land-use suitability mapping and modelling (Malczewski, 2004 and Malczewski, 2006). This paper addresses a scientific approach to determine suitable land for healthy urban development. This 
approach will help in revision of policy and preparation of development plans in the study area and for other cities as well.

\section{Study area}

The study covers the locations of public parks for Larkana city of Pakistan. Larkana is the most important settlement in upper western Sindh; located at $27^{\circ} 33^{\prime}$-north latitudes and $68^{\circ} 12^{\prime}$-east longitudes. The average population growth rate of Larkana experienced an increase of about $3.0 \%$ to $3.2 \%$ per year in the period of 1951 to 1998. Assuming the same growth rate, the population of Larkana will increase from 270,283 in 1998 to 400,550 in 2010 and 544,200 in 2020 ( Larkana development plan, 2000-2020). The location map of Larkana city is shown in Fig. 1.

\section{Methodology}

The GIS- based land suitability analysis using AHP (Joerin et al., 2001) approach as the multi-criteria decision analysis (MCDA) was used in this research study. It allows integrated GIS-based land suitability modelling for site suitability (Mendoza, 1997). It is a logically ordered procedure that works by breaking down a problem into its smaller and smaller elements which helps decision makers all the way (Saaty, 1985). The AHP is a systematic method to guide decision-makers in making decisions to solve the problems based on priorities (Miller et. al., 1998). However, AHP manages the several criteria/factors of a problem into a hierarchy related to a tree form arrangement. The goal level is the uppermost level, which defines the problem. The second level is the level of criteria/factors comprising three aspects: land availability, accessibility and socio-economic. The third level consists of various sub-criteria/parameters. Figure 2 depicts the hierarchy structure of almost all the decision factors based on the expert's discussions, which were applied in this study. The relevant factors of the land suitability analysis were selected based on literature surveys and discussion with experts. Further factors were categorized into relevant parameters. Keeping in view, the alternatives (Scenarios) based on the criteria and parameters were determined using the pair-wise comparison matrix as shown in Table 4, 6, and 8 .

\subsection{Data collection}

The spatial and non-spatial data was collected from the department of Town Planning, Hyderabad, and municipal authorities of Larkana, Sindh (Pakistan). The obtained data is shown in Table 1. It was easy to get data through formal requests. There were some limitations, e.g. time constraint and sensitive area information.

\subsection{GIS data base development}

GIS data base development of this study was developed by using criteria and sub-criteria that is indicated in Table 2. The base map of Larkana city was scanned and fixed geo-referencing to change it into earth coordinates, then it was digitized in ArcGIS 9.2 software to develop data layers.

\subsection{Development of the pairwise comparison matrix}

Matrixes of pairwise comparisons were created by the experts on condition that judgments are evaluated to find suitable alternatives to estimate associated absolute numbers from 1 to 9 , the fundamental scales of the AHP (Saaty, 2007) exhibited in Table 3. Three alternative scenarios were produced by using AHP in the suitable site selection of parks. The AHP is the rational planning process in locating public facilities (Banai-Kashani, 1989).

\subsection{Computation of the pairwise comparison matrix}

Table 2 exhibits the criteria and sub-criteria, considered in land suitability analysis to create three alternatives (scenarios) by using the ArcGIS 9.2 spatial analysis tool, which includes (1) land availability, (2) land value and (3) population density.

The weights of factors and parameters were successfully calculated easily for land suitability with the Expert Choice 11.5 software (Lee and Chan, 2008), keeping in view the consistency ratio (CR). If CR is satisfactory, it does not exceed the desired range, i.e. $>0.10$. If the $\mathrm{CR}$ value is in an undesirable range, the obtained judgement matrix is needed to be reviewed till these values have improved and are satisfactory. The AHP software, Expert Choice can calculate automatically. Indeed, it was a time consuming procedure to compute the pairwise comparison matrix manually or in MsExcel. Therefore, Expert Choice is a multi-objective decision support tool based on AHP (Saaty, 2003).

Later on, to compute composite weights, Eastman et al., 1995 stated two procedures for multi-criteria evaluation: the concordance discordance analysis and the weighted linear combination. The function of a weighted linear combination (WLC) procedure where each factor and parameter (Vi) are multiplied by the weight of the suitability parameters (Wi) to get composite weights and then summed as shown in Table 4, 6 and 8 . WLC is a straight forward linear method calculating composite weights. Similarly, the results of composite weights based on alternatives (scenarios) were used in a weighted sum spatial analysis function. This function multiplies and sums up the layers to produce scenarios suitability maps for parks which are presented in Fig. 3, 4 and 5.

Therefore, the weighted linear technique (Mendoza, 1997; Mohit and Ali, 2006) was applied to yield a suitability map by the following formula: 


$$
E=\sum_{i=1}^{n} w i * v i
$$

Where: $\mathrm{Wi}=$ relative importance or weight of factors/parameters $\mathrm{i}$,

$\mathrm{Vi}=$ relative weight of parameters $\mathrm{i}$,

and $n=$ total number of parameters related to the study.

\section{GIS based Land Suitability Analysis}

The land suitability analysis was performed in the raster format. The raster data model is the more suitable technique because the structure of raster data is grid cell based, which can easily delineate suitable sites. Raster data facilitates the user in carrying out a weighted overlay on numerous layers. Suitability maps were created under a raster GIS environment, based on various scenarios. The suitability for each land use was analyzed in ArcGIS 9.2 to locate suitable areas for parks.

\section{Results and Discussion}

The AHP method was used to evaluate the priority weight of each factor and sub-criteria (parameters). AHP and the Geographic Information System (GIS) are an integrated technique used to assess suitable land for public parks in Larkana City (Thapa, 2008). The derivation of relative composite weights of land suitability factors and parameters based on land availability scenario 1 was calculated as presented in Table 4 . In a similar way, scenario 2, land value; and scenario 3, population density, were also analyzed and mentioned in Table 6 and Table 8 . The cell size was $(5 \times 5)$ and total grid cells were $(388,377)$ for this study area. The land suitable for public parks based on AHP by using GIS in scenario 1 results in; out of 388,377 grid cells, $383,39(10 \%$ or 95.8 hectares) are potential land, 246,353 (63\% or 615.8 hectares) are least potential land and $103,685(27 \%$ or 259.2 hectares) are constraint; this is depicted as degree of land suitability scenario1 in Table 5. Fig. 3 shows the potential areas for different land uses based on scenario 1 in the city.

In degree of land suitability scenario 2: $247,692(64 \%$ or 619.2 hectares) of the grid cells are potential land, $56,763(15 \%$ or 141.9 hectares) are least potential land and $83,922(21 \%$ or 209.8 hectares) are constraint; this is shown in Table 7. Potential land based on the land value scenario in the city is presented in Fig. 4. Finally, $270,033(69 \%$ or 675 hectares) are potential land, $100,778(26 \%$ or 251.9 hectares) are least potential land and $17,566(5 \%$ or 43.9 hectares) are constraint out of 388,377 grid cells as illustrated in Table 9 degree of land suitability scenario3. Fig. 5 shows the potential areas based on the land density scenario in the city.

\subsection{Evaluation of potential land based on scenarios}

All three scenarios were combined to determine potential land. As stated in Table 10, 256,698 grids (66\% or 641.7 hectares) are potential land, 58,185 grids ( $15 \%$ or 145.4 hectares) are least potential land and 73,494 grids (19\% or 183.7 hectares) are constraint for parks development. Fig. 6 illustrates the potential land map for parks in Larkana City.

\subsection{Evaluation of most suitable land for parks based on scenarios}

It is shown in Table 11 that 4,543 grids ( $1.2 \%$ or 11.3 hectares) are most suitable, 514 grids $(0.2 \%$ or 1.2 hectares) are least suitable and 383,320 grids ( $98 \%$ or 958.3 hectares) are not suitable for parks planning. Furthermore, Fig. 7 shows the most suitable land for parks.

GIS-based AHP as a multi-criteria evaluation approach was applied in the present study. The main advantage of this appraoch is that it can be done quickly utilizing the data processing and capabilities of GIS in the land use decision making process (Store, 2001). Therefore, the results of this study will be useful with GIS-based land suitability analysis modelling in land-use planning and development plans in the future. The development plans can be successful if this study methodolology is included in the planning process.

\section{Conclusion}

This study has focused the use of integrated multi-criteria AHP with GIS to determine the suitability of the land for parks in the city of Larkana. The sustainable planning approach has not been considered before in urban development that is needed essentially for growth of the city. However, GIS-based AHP as MCDA in the land suitability analysis approach can be useful to determine suitable land in urban development. Planning standards of optimal locations are not the only important consideration in the planning process, but also sustainable distances from facilities to people should also be considered. The results show that scenario 3 (Population density) obtained the highest percentage of potential land (69\%), while scenario 2 (land value) obtained $64 \%$ and scenario1 (Land availability) $10 \%$.

This study can provide a framework for the planning process by using GIS and the multi-criteria decision analysis making (MCDM) approach for Larkana city planning. Therefore, this study presented the advantages of integrated GIS-based land suitability analysis and a solution for such complicated decisions. It can also provide an important guidance for future land use changes and cost effective solutions in the cities, where conditions are similar as in Pakistan. 


\section{Acknowledgement}

We wish to express our profound gratitude to our able supervisors whom in their diverse ways have helped us in the successful completion of this study despite their immeasurable commitments.

\section{References}

Adeel, M. (2010). Methodology for identifying urban growth potential using land use and population data: A case study of Islamabad Zone IV. Procedia Environmental Sciences, 2, 32-41.

Abadi. (2007). Integrated coastal land use development using analytic network process and GIS: Case of Kuala Langat District, Malaysia. (PhD Thesis).

Barbosa,O., Tratalos, J.A., Armsworth,P.R., Davies, R.G., Fuller, R.A., Johnson,P., Gaston,K.J. (2007). Who benefits from access to green space? A case study from Sheffield, UK. Landscape and Urban Planning, 83, 187-195.

Banai-Kashani, R. (1989). A new method for site suitability analysis: the analytic hierarchy process. Environmental Management, 13, 685-693.

Graymore ,M.L.M., Wallis, A. M., Richards, A., J. (2009). An Index of Regional Sustainability: A GIS-based multiple criteria analysis decision support system for progressing sustainability. Ecological Complexity, 6, 453-462.

Hein,W.N. and Jusuf, S.K. (2008). GIS-based Greenery evaluation on campus master plan. Landscape and Urban Planning, 84, 166-182.

Joerin, F., Theriault, M., and Musy, A. (2001). Using GIS and outranking multicriteria analysis for land-use suitability assessment. Int. j. of geographical information science, vol. 15, No. 2, 153-174.

Lee,K.L.G. and Chan,E.H.W. (2008). The Analytic Hierarchy Process (AHP) Approach for Assessment of Urban Renewal Proposals. Soc Indic Res., 89, 55-168.

Mohit, A. and Ali, M. (2006). Integrating GIS and AHP for land sutiabiltiy Analysis for Urban Development in a Secondary City of Bangladesh. Journal alam Bina, Jilid 8, No 1.

Mendoza, G.A. (1997). A GIS-based multicriteria approach to land use suitability assessment and allocation. J.M. Vasievich, J.S. Fried, and L.A. Leefers (eds.). 7th Symposium on Systems Analysis in Forest Resources. GTR-NC-205. U.S. Forest Service, St. Paul, Minnesota.

Malczewski,J. (2006). GIS-based multicriteria decision analysis: a survey of the literature. International Journal of Geographical Information Science, Vol. 20, No. 7, 703-726.

Malczewski, J. (2004). GIS-based land-use suitability analysis: a critical overview. Progress in Planning, 62, 3-65.

Miller, W. C. (1998). An approach for greenway suitability analysis. Landscape and Urban Planning, 42, 91-105.

Maruani,T. and Amit-Chen,I. (2007). Open space planning models: A review of approaches and methods. Landscape and Urban planning, 81, 1-13.

Murray, A.T. (2003). Site placement uncertainty in location analysis. Computers, Environment and Urban Systems, 27, 205-221.

Saaty,T.L. and Kearns, K.P. (1985). Analytical planning the organization of systems. ( $1^{\text {st }}$ ed.). NewYork, USA: Pergamon press.

Saaty,T.L. (2007). Time dependent decision-making; dynamic priorities in the AHP/ANP: Generalizing from points to functions and from real to complex variables. Mathematical and Computer Modelling, 46, 860-891.

Store, R. and Kangas, J. (2001). Integration spatial multi-criteria evaluation and expert knowledge for GIS-based habitat suitability modelling. Landscape and Urban Planning, 55, 79-93.

Thapa,R.B. and Murayama, Y. (2008). Land evaluation for peri-urban agriculture using analytical hierarchical process and geographic information system techniques: A case study of Hanoi. Land use polic,. 25, $225-239$.

Thompson,C.T. (2002). Urban open space in the 21st century. Landscape and Urban Planning, 60, 59-72.

Uy and Nakagoshi. (2008). Application of land suitability analysis and landscape ecology to urban greenspace planning in Hanoi, Vietnam. Urban Forestry \& Urban Greening, 7,25-40.

Table 1. Data types and sources

\begin{tabular}{|l|l|l|}
\hline Data & Types & Sources \\
\hline Base map (Land- uses) & Spatial & Town planning department, Hyderabad \\
\hline Land value & Non-spatial & Market survey, Municipal authority \\
\hline Population density & Non-spatial & Development plan of Larkana city (2000-2020) \\
\hline Income level & Non-Spatial & Development plan of Larkana city (2000-2020) \\
\hline
\end{tabular}


Table 2. Criteria and sub-criteria/parameters (Vi)

\begin{tabular}{|c|c|c|c|}
\hline Criteria/Factors & \multicolumn{3}{|c|}{ Sub-criteria(Parameters) } \\
\hline \multirow[t]{4}{*}{ Land Availability } & \multirow[t]{2}{*}{ Vacant land } & \multicolumn{2}{|l|}{ Public } \\
\hline & & \multicolumn{2}{|l|}{ Private } \\
\hline & \multirow{2}{*}{\multicolumn{2}{|c|}{ Existing Parks }} & City Parks \\
\hline & & & Mohalla Parks \\
\hline \multirow[t]{3}{*}{ Land Price/Value } & \multirow{3}{*}{\multicolumn{2}{|c|}{ Land value (sq. ft) }} & High \\
\hline & & & Medium \\
\hline & & & Low \\
\hline \multirow[t]{2}{*}{ Accessibility } & \multirow[t]{2}{*}{ Roads } & \multicolumn{2}{|l|}{ Major Roads } \\
\hline & & \multicolumn{2}{|l|}{ Local Roads } \\
\hline \multirow[t]{6}{*}{ Socio-Economic } & \multirow{3}{*}{$\begin{array}{l}\text { Population } \\
\text { Density }\end{array}$} & \multicolumn{2}{|l|}{ High } \\
\hline & & \multicolumn{2}{|l|}{ Medium } \\
\hline & & \multicolumn{2}{|l|}{ Low } \\
\hline & \multirow[t]{3}{*}{ Income group/level } & \multicolumn{2}{|l|}{ High } \\
\hline & & \multicolumn{2}{|l|}{ Middle } \\
\hline & & \multicolumn{2}{|l|}{ Low } \\
\hline
\end{tabular}

Table 3. AHP Scale of Relative Importance

\begin{tabular}{|l|l|l|}
\hline $\begin{array}{l}\text { Intensity of relative } \\
\text { importance }\end{array}$ & Definition & Explanation \\
\hline 1 & Equal Importance & $\begin{array}{l}\text { Two activities combine } \\
\text { equally to the objective. }\end{array}$ \\
\hline 3 & Moderate importance of one over another & $\begin{array}{l}\text { Experience and judgment } \\
\text { slightly favour one activity } \\
\text { over another. }\end{array}$ \\
\hline 7 & Essential or strong importance & $\begin{array}{l}\text { Experience and judgment } \\
\text { strongly favour one activity } \\
\text { over another. }\end{array}$ \\
\hline 9 & Demonstrated importance & $\begin{array}{l}\text { An Activity is strongly } \\
\text { favoured and its dominance is } \\
\text { demonstrated in practice. }\end{array}$ \\
\hline $\begin{array}{l}\text { Reciprocals of above } \\
\text { non-zero numbers. }\end{array}$ & $\begin{array}{l}\text { If axtreme Importance } \\
\text { numbers (e.g. 3) compared with a second } \\
\text { activity, then the second activity has the } \\
\text { reciprocal value (i.e.1/3) when compared } \\
\text { to the first. }\end{array}$ & $\begin{array}{l}\text { The evidence favouring one } \\
\text { activity over another is of the } \\
\text { highest possible order of } \\
\text { affirmation. }\end{array}$ \\
\hline
\end{tabular}

Source: Saaty (1985) 
Table 4. Derivation of Relative Composite Weight of Land Suitability Factors and Parameters based on Land availability Scenario (Wi)

\begin{tabular}{|c|c|c|c|c|c|}
\hline Criteria/ & \multicolumn{3}{|c|}{ Sub-criteria(Parameters) } & Composite & Weight \\
\hline \multirow{6}{*}{ Land Availability } & \multirow[t]{2}{*}{ Vacant land } & \multicolumn{2}{|l|}{ Public } & 0.28 & 28 \\
\hline & & \multicolumn{2}{|l|}{$\begin{array}{l}\text { Private } \\
\end{array}$} & 0.06 & 6 \\
\hline & \multicolumn{3}{|l|}{ Sub-total } & 0.34 & 34 \\
\hline & \multirow{2}{*}{\multicolumn{2}{|c|}{ Existing Parks }} & City Parks & 0.07 & 7 \\
\hline & & & Mohalla parks & 0.04 & 4 \\
\hline & \multicolumn{3}{|l|}{ Sub-total } & 0.11 & 11 \\
\hline \multirow[t]{4}{*}{ Land Price/Value } & \multirow{3}{*}{\multicolumn{2}{|c|}{ Land Value (sq/ft) }} & High & 0.02 & 2 \\
\hline & & & Medium & 0.04 & 4 \\
\hline & & & Low & 0.07 & 7 \\
\hline & \multicolumn{3}{|l|}{ Sub-total } & 0.13 & 13 \\
\hline \multirow[t]{3}{*}{ Accessibility } & \multirow[t]{2}{*}{ Roads } & \multicolumn{2}{|c|}{ Major Roads } & 0.05 & 5 \\
\hline & & \multicolumn{2}{|c|}{ Local Roads } & 0.12 & 12 \\
\hline & \multicolumn{3}{|l|}{ Sub-total } & 0.17 & 17 \\
\hline \multirow[t]{8}{*}{ Socio-Economic } & \multirow{3}{*}{$\begin{array}{l}\text { Population } \\
\text { Density }\end{array}$} & \multicolumn{2}{|l|}{ High } & 0.08 & 8 \\
\hline & & \multicolumn{2}{|l|}{ Medium } & 0.05 & 5 \\
\hline & & \multicolumn{2}{|l|}{ Low } & 0.03 & 3 \\
\hline & \multicolumn{3}{|l|}{ Sub-total } & 0.16 & 16 \\
\hline & \multirow{3}{*}{$\begin{array}{l}\text { Income } \\
\text { group/level }\end{array}$} & \multicolumn{2}{|l|}{ High } & 0.03 & 3 \\
\hline & & \multicolumn{2}{|l|}{ Middle } & 0.04 & 4 \\
\hline & & \multicolumn{2}{|l|}{ Low } & 0.02 & 2 \\
\hline & \multicolumn{3}{|l|}{ Sub-total } & 0.09 & 9 \\
\hline \multicolumn{2}{|c|}{ Total Weight age $\left(\sum \mathrm{wi}=1.0\right)$} & & & 1.00 & 100 \\
\hline
\end{tabular}

Table 5. Degree of Land suitability scenario1 (Land availability)

\begin{tabular}{|l|l|l|l|}
\hline \multirow{2}{*}{ Degree of Suitability } & Scenario1 & \multicolumn{2}{|l|}{} \\
\cline { 2 - 4 } & Grid Cell Nos. & $\begin{array}{l}\text { Area } \\
\text { (Hectares) }\end{array}$ & Percentage \\
\hline Potential & 38,339 & 95.8 & 10 \\
\hline Least potential & 246,353 & 615.8 & 63 \\
\hline Constraint & 103685 & 259.2 & 27 \\
\hline Total & $\begin{array}{l}388,377 \\
(100)\end{array}$ & 970.9 & 100 \\
\hline
\end{tabular}


Table 6. Derivation of Relative Composite Weight of Land Suitability Factors and Parameters based on Land value Scenario (Wi)

\begin{tabular}{|c|c|c|c|c|c|}
\hline Criteria/Factors & \multicolumn{3}{|c|}{ Sub-criteria(Parameters) } & $\begin{array}{l}\text { Composite } \\
\text { weight (Wi) }\end{array}$ & $\begin{array}{l}\text { Weight } \\
\text { (Wi) }\end{array}$ \\
\hline \multirow[t]{6}{*}{ Land Availability } & \multirow[t]{2}{*}{ Vacant land } & \multicolumn{2}{|l|}{ Public } & 0.14 & 14 \\
\hline & & \multicolumn{2}{|l|}{ Private } & 0.02 & 2 \\
\hline & \multicolumn{3}{|l|}{ Sub-total } & 0.16 & 16 \\
\hline & \multirow{2}{*}{\multicolumn{2}{|c|}{ Existing Parks }} & City Parks & 0.06 & 7 \\
\hline & & & Mohalla Parks & 0.04 & 4 \\
\hline & \multicolumn{3}{|l|}{ Sub-total } & 0.1 & 10 \\
\hline \multirow[t]{4}{*}{ Land Price/Value } & \multirow{3}{*}{\multicolumn{2}{|c|}{ Land Value (sq. ft) }} & High & 0.05 & 5 \\
\hline & & & Medium & 0.17 & 17 \\
\hline & & & Low & 0.29 & 29 \\
\hline & \multicolumn{3}{|l|}{ Sub-total } & 0.51 & 51 \\
\hline \multirow{3}{*}{ Accessibility } & \multirow{2}{*}{ Roads } & \multicolumn{2}{|l|}{ Major Roads } & 0.03 & 3 \\
\hline & & \multicolumn{2}{|l|}{ Local Roads } & 0.07 & 7 \\
\hline & \multicolumn{3}{|l|}{ Sub-total } & 0.1 & 10 \\
\hline \multirow[t]{8}{*}{ Socio-Economic } & \multirow{3}{*}{$\begin{array}{l}\text { Population } \\
\text { Density }\end{array}$} & \multicolumn{2}{|l|}{ High } & 0.03 & 3 \\
\hline & & \multicolumn{2}{|l|}{ Medium } & 0.05 & 5 \\
\hline & & \multicolumn{2}{|l|}{ Low } & 0.01 & 1 \\
\hline & \multicolumn{3}{|l|}{ Sub-total } & 0.09 & 9 \\
\hline & \multirow{3}{*}{$\begin{array}{l}\text { Income } \\
\text { group/level }\end{array}$} & \multicolumn{2}{|l|}{ High } & 0.01 & 1 \\
\hline & & \multicolumn{2}{|l|}{ Middle } & 0.02 & 2 \\
\hline & & \multicolumn{2}{|l|}{ Low } & 0.01 & 1 \\
\hline & \multicolumn{3}{|l|}{ Sub-total } & 0.04 & 4 \\
\hline $\begin{array}{l}\text { Total Weight age } \\
\left(\sum \mathrm{Wi}=1.0\right)\end{array}$ & \multicolumn{3}{|l|}{ 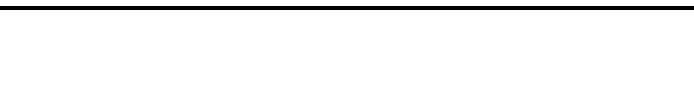 } & 1.00 & 100 \\
\hline
\end{tabular}

Table 7. Degree of Land suitability scenario 2 (Land value)

\begin{tabular}{|l|l|l|l|}
\hline Degree of Suitability & Scenario 2 & Percentage \\
\cline { 2 - 4 } & Grid Cell Nos. & $\begin{array}{l}\text { Area } \\
\text { (Hectares) }\end{array}$ & 64 \\
\hline Potential & 247,692 & 619.2 & 15 \\
\hline Least potential & 56,763 & 141.9 & 21 \\
\hline Constraint & 83,922 & 209.8 & 100 \\
\hline Total & $\begin{array}{l}388,377 \\
(100)\end{array}$ & 970.9 & \\
\hline
\end{tabular}


Table 8. Derivation of Relative Composite Weight of Land Suitability Factors and Parameters based on population density scenario (Wi)

\begin{tabular}{|c|c|c|c|c|c|c|}
\hline Criteria/Factors & \multicolumn{4}{|c|}{ Sub-criteria(Parameters) } & $\begin{array}{l}\text { Composite } \\
\text { weight (Wi) }\end{array}$ & $\begin{array}{l}\text { Weight } \\
\text { (Wi) }\end{array}$ \\
\hline \multirow{6}{*}{ Land Availability } & \multirow[t]{2}{*}{ Vacant land } & \multicolumn{3}{|c|}{ Public } & 0.12 & 12 \\
\hline & & \multicolumn{3}{|c|}{ Private } & 0.02 & 2 \\
\hline & \multicolumn{4}{|l|}{ Sub-total } & 0.14 & 14 \\
\hline & \multirow{2}{*}{\multicolumn{2}{|c|}{ Existing Parks }} & \multicolumn{2}{|c|}{ City Parks } & 0.04 & 4 \\
\hline & & & \multirow{2}{*}{\multicolumn{2}{|c|}{ Mohalla parks }} & 0.02 & 2 \\
\hline & \multicolumn{2}{|c|}{ Sub-total } & & & 0.06 & 6 \\
\hline \multirow[t]{4}{*}{ Land Price/Value } & \multirow{3}{*}{\multicolumn{3}{|c|}{ Land value (sqft) }} & High & 0.01 & 1 \\
\hline & & & & Medium & 0.1 & 10 \\
\hline & & & & Low & 0.1 & 10 \\
\hline & \multicolumn{4}{|l|}{ Sub-total } & 0.21 & 21 \\
\hline \multirow[t]{3}{*}{ Accessibility } & \multirow[t]{2}{*}{ Roads } & \multicolumn{3}{|c|}{ Major Roads } & 0.03 & 3 \\
\hline & & \multicolumn{3}{|c|}{ Local Roads } & 0.05 & 5 \\
\hline & \multicolumn{4}{|l|}{ Sub-total } & 0.08 & 8 \\
\hline \multirow[t]{8}{*}{ Socio-Economic } & \multirow{3}{*}{$\begin{array}{l}\text { Population } \\
\text { Density }\end{array}$} & \multicolumn{3}{|c|}{ High } & 0.19 & 19 \\
\hline & & \multicolumn{3}{|c|}{ Medium } & 0.11 & 11 \\
\hline & & \multicolumn{3}{|c|}{ Low } & 0.05 & 5 \\
\hline & \multicolumn{4}{|l|}{ Sub-total } & 0.35 & 35 \\
\hline & \multirow{3}{*}{$\begin{array}{l}\text { Income } \\
\text { group/level }\end{array}$} & \multicolumn{3}{|c|}{ High } & 0.02 & 2 \\
\hline & & \multicolumn{3}{|c|}{ Middle } & 0.05 & 5 \\
\hline & & \multicolumn{3}{|c|}{ Low } & 0.09 & 9 \\
\hline & \multicolumn{4}{|l|}{ Sub-total } & 0.16 & 16 \\
\hline $\begin{array}{l}\text { Total Weight age } \\
\left(\sum \mathrm{Wi}=1.0\right)\end{array}$ & & & & & 1.00 & 100 \\
\hline
\end{tabular}

Table 9. Degree of Land suitability scenario 3 (Population density)

\begin{tabular}{|l|l|l|l|}
\hline \multirow{2}{*}{ Degree of Suitability } & Scenario 3 & \multicolumn{2}{|l|}{} \\
\cline { 2 - 4 } & Grid Cell Nos. & $\begin{array}{l}\text { Area } \\
\text { (Hectares) }\end{array}$ & Percentage \\
\hline Potential & 270,033 & 675 & 69 \\
\hline Least potential & 100,778 & 251.9 & 26 \\
\hline Constraint & 17,566 & 43.9 & 5 \\
\hline Total & $\begin{array}{l}388,377 \\
(100)\end{array}$ & 970.9 & 100 \\
\hline
\end{tabular}

Table 10. Land suitability for Public parks

\begin{tabular}{|l|l|l|l|}
\hline Land for parks development. & Grid Cell Nos. & Area(Hectares) & Percentage \\
\hline Potential & 256,698 & 641.7 & 66 \\
\hline Least potential & 58,185 & 145.46 & 15 \\
\hline Constraint & 73,494 & 183.7 & 19 \\
\hline
\end{tabular}

Table 11. Most suitable land for Parks

\begin{tabular}{|l|l|l|l|}
\hline Land for Parks development & Grid cell nos. & Area(Hectares) & Percentage \\
\hline Not suitable & 383,320 & 958.3 & 98.6 \\
\hline Least suitable & 514 & 1.2 & 0.2 \\
\hline Most suitable & 4,543 & 11.3 & 1.2 \\
\hline
\end{tabular}




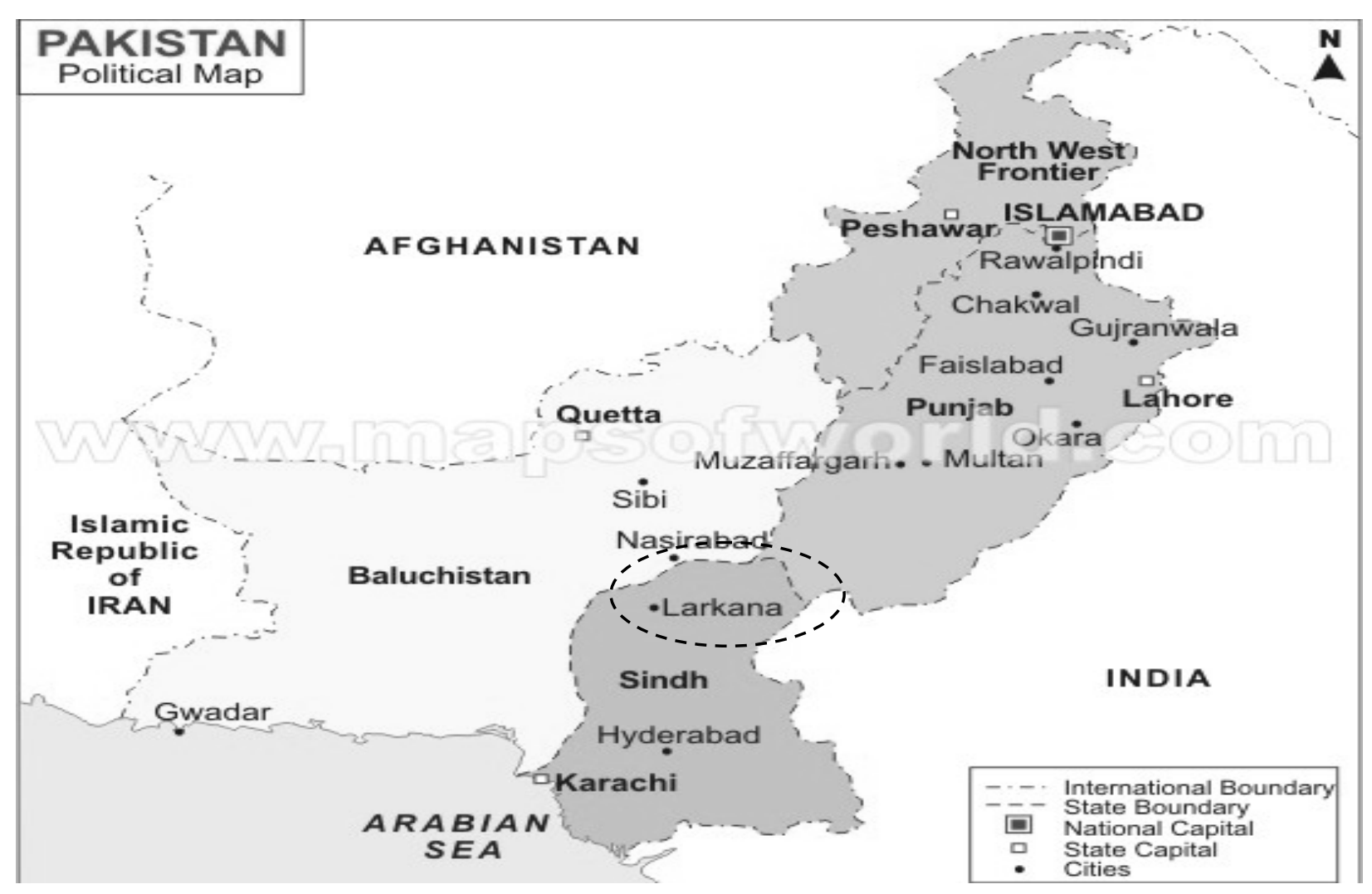

Figure 1. Location map of Larkana city 


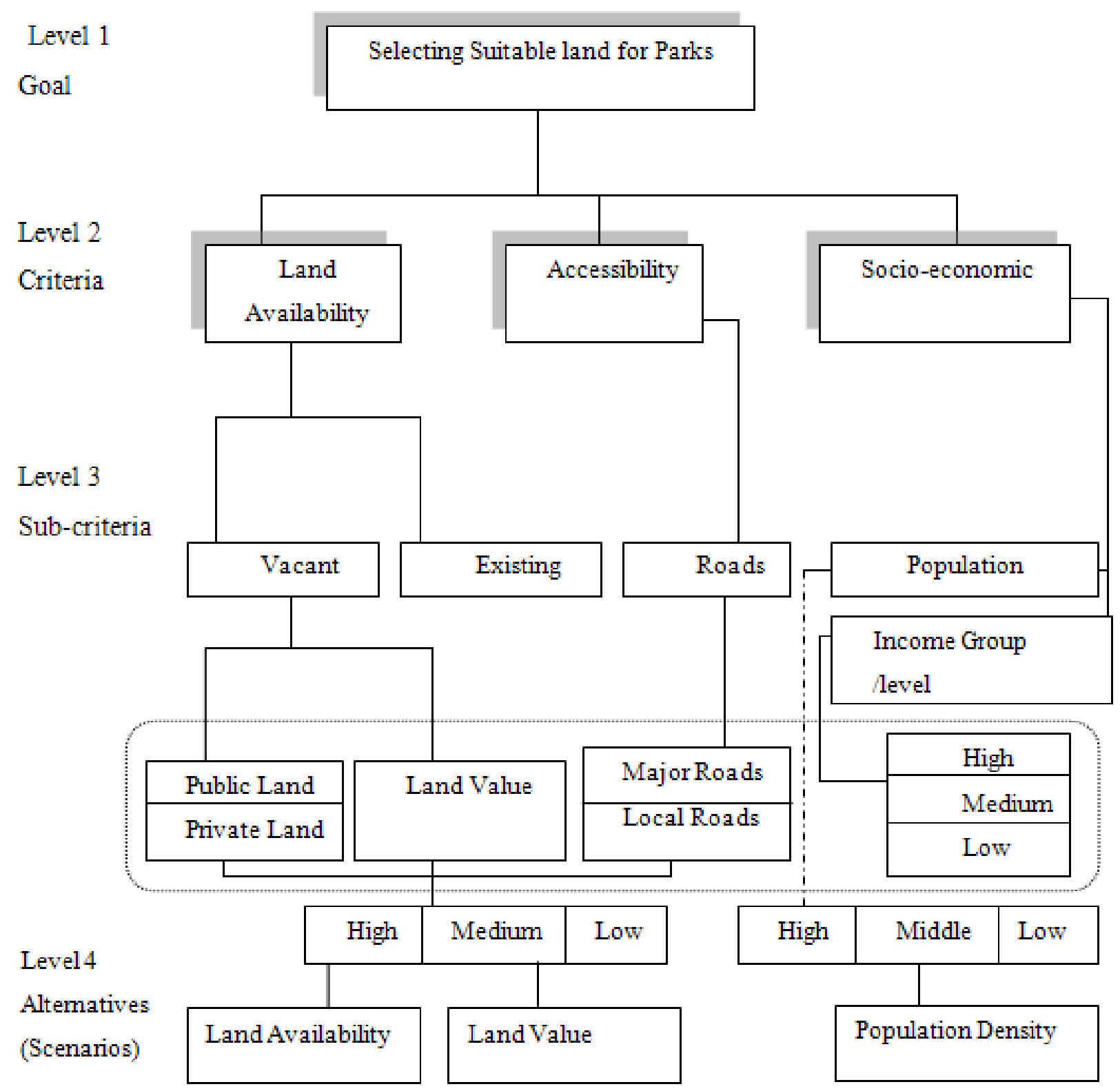

Figure 2. Hierarchical Structure Model of Selecting suitable Land for Parks 

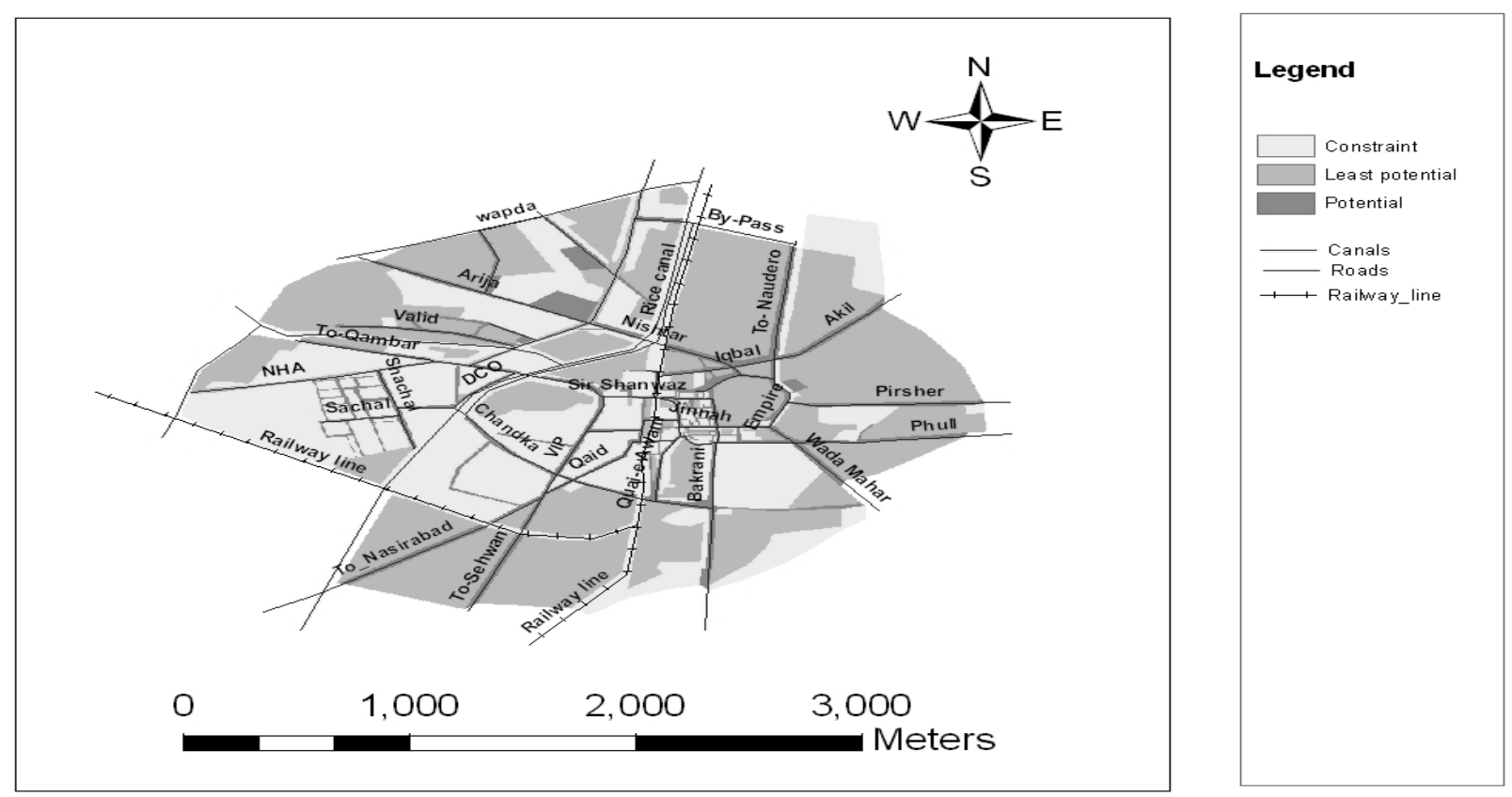

Figure 3. Scenario1 (Land availability)
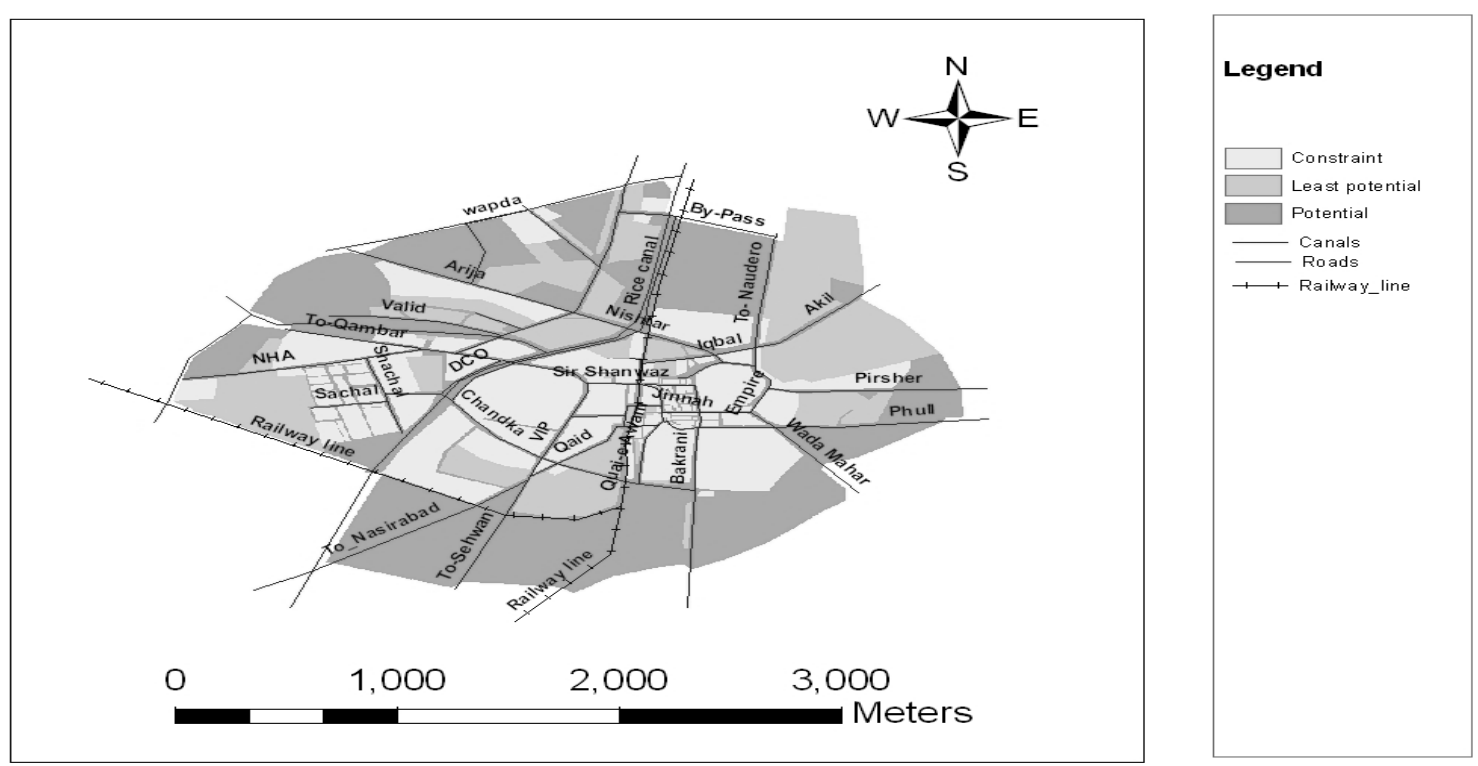

Figure 4. Scenario 2 (Land value) 

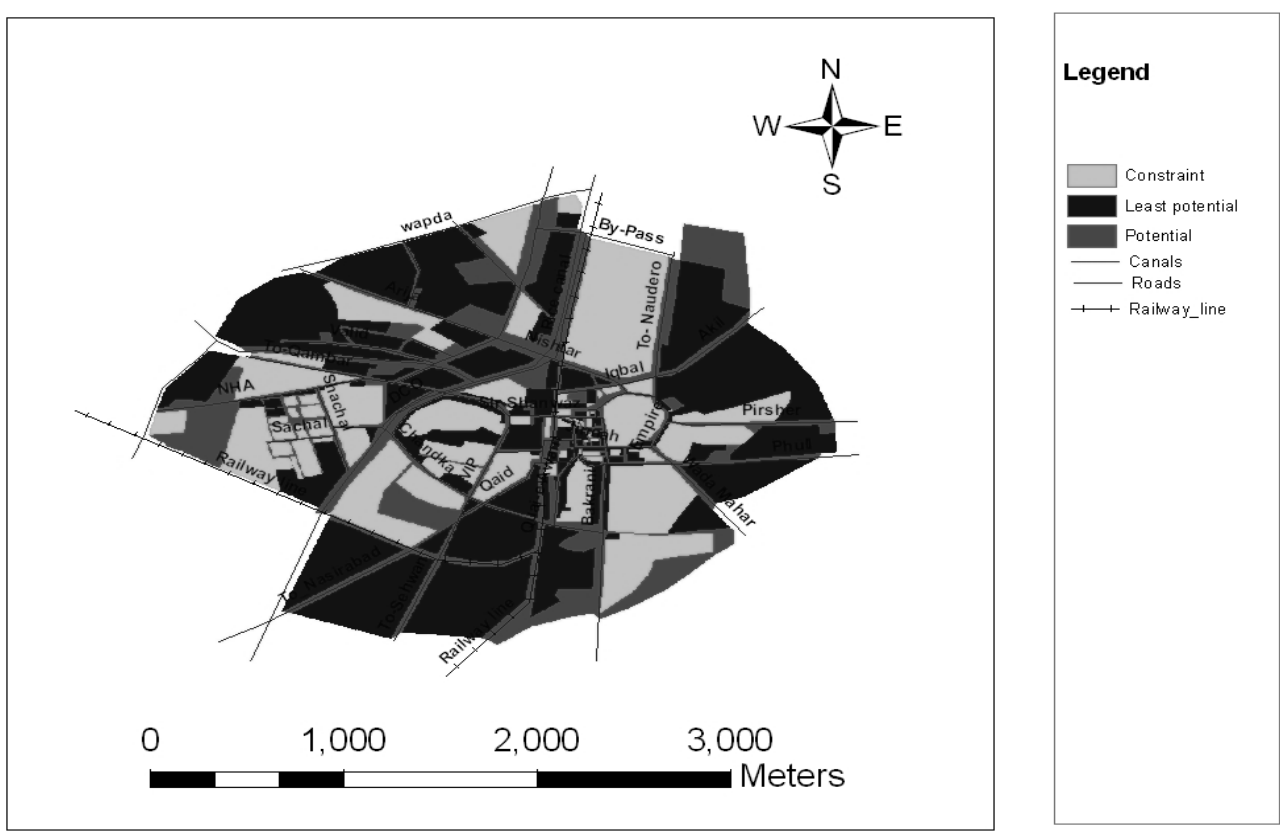

Figure 5. Scenario 3 (Population density)
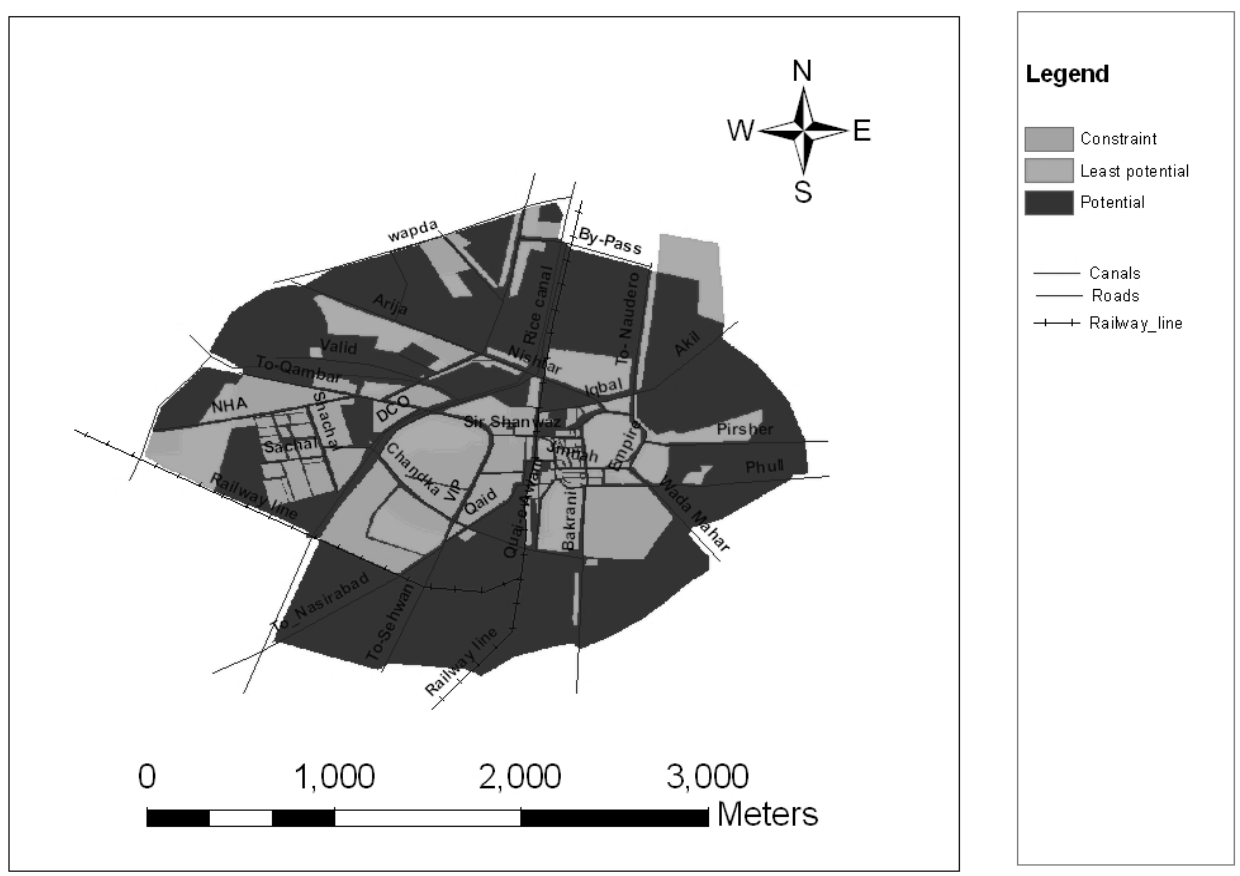

Figure 6. Potential land for parks in Larkana City 

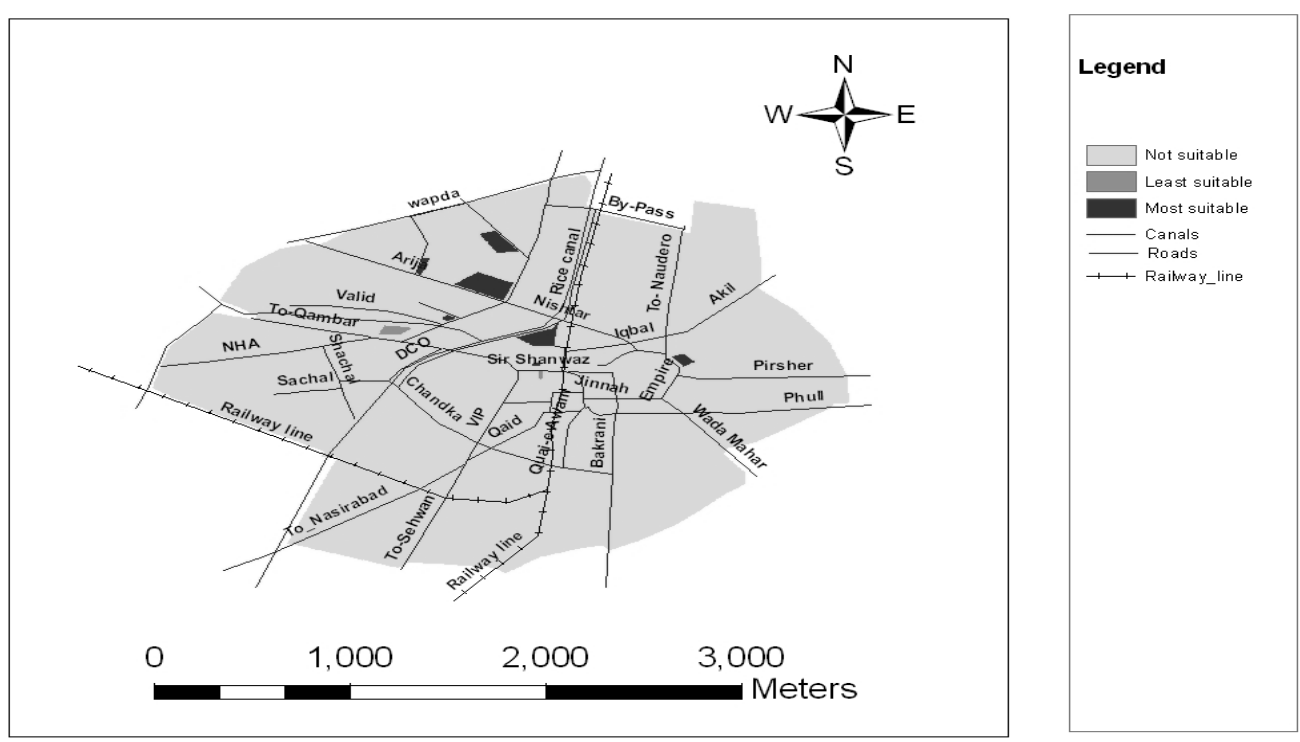

Figure 7. Most suitable land 